\title{
Pengaruh Kualitas Pelayanan Terhadap Kepuasan Pengunjung di Monumen Nasional Jakarta
}

\author{
Rahmat Priyanto ${ }^{1}$, Intan Mahfud ${ }^{2}$ \\ ${ }^{1}$ STP Ars Internasional, rahmat.rmp@bsi.ac.id \\ ${ }^{2}$ STP Ars Internasional, intanlorin5@gmail.com
}

\begin{abstract}
Abstrak
Monumen Nasional Jakarta merupakan monumen yang menjadi ciri khas Kota Jakarta. Monumen Nasional menawarkan daya tarik wisata berupa sejarah mengenai perjuangan bangsa Indonesia. Kualitas pelayanan merupakan faktor penting yang harus diperhatikan oleh setiap perusahaan. Karena kualitas pelayanan sangat erat kaitanya dengan kepuasan pengunjung. Tujuan dalam penelitian ini untuk menganalisis sejauhmana pengaruh kualitas pelayanan terhadap kepuasan pengunjung di monumen nasional Jakarta. Metode yang digunakan dalam penelitian ini adalah kuantitatif dengan pendekatan deskriptif verifikatif. Sumber data dalam penelitian ini diperoleh melalui kegiatan wawancara, observasi, quisioner dan literature dari penelitian terdahulu atau jurnal. Populasi dalam penelitian ini merupakan wisatawan yang melakukan kunjungan ke Monumen Nasional. Hasil penelitian ini menunjukan bahwa Kualitas Pelayanan memiliki korelasi yang tidak besar terhadap Kepuasan Pengunjung namun Kualitas Pelayanan berpengaruh secara signifikan terhadap kepuasan pengunjung di Monumen Nasional Jakarta.
\end{abstract}

Kata kunci : Pelayanan Prima, Kualitas Pelayanan dan Kepuasan Pengunjung

\begin{abstract}
Jakarta National Monument is a monument that is a characteristic of the Jakarta City. The National Monument offers a tourist attraction containing history about the struggle of the Indonesian people. Service quality is an important factor that must be considered by every company. Because service quality is very closely related to visitor satisfaction. The purpose of this study was to analyze the improvement of service quality towards visitor satisfaction at the Jakarta national monument. The method used in this research is quantitative by using descriptive verification. Sources of data in this study were obtained through interviews, observation, questionnaires and literature from previous research or journals. The population in this study were tourists who visited the National Monument. The results of this study indicate that Service Quality must be considered greater towards Visitor Satisfaction but Quality of Service is important for visitors at the Jakarta National Monument.
\end{abstract}

Keywords: Service Excellent, Service Quality and Visitor Satisfaction.

Diterima: 20 Februari 2019, Direvisi: 10 April 2019, Diterbitkan: 15 Agustus 2019 


\section{PENDAHULUAN}

Pariwisata saat ini menjadi salah satu industri yang berkembang pesat di Indonesia, melalui berbagai rencana pembangunan dan pengembangan pariwisata yang dilakukan oleh pemerintah, maka pariwisata diharapkan dapat terus tumbuh secara signifikan agar mampu meningkatkan perekonomian negara melalui kegiatan pariwisata. Indonesia memiliki wilayah yang sangat luas dan didukung sumber daya alam yang beraneka ragam. Selain itu Indonesia juga kaya akan seni budaya daerah, adat istiadat dan peninggalan sejarah terdahulu yang mampu menjadi potensi dalam mengembangkan dan meningkatkan industri kepariwisataanya.

Jakarta sebagai ibu kota Indonesia, memiliki potensi kepariwisatan yang sangat baik, hal tersebut didukung dengan berbagai destinasi wisata menarik yang berada di Jakarta, baik wisata pantai, sejarah maupun wisata buatan. Selain itu dengan ditetapkanya Jakarta sebagai ibu kota negara, maka hal tersebut memberikan kesan yang baik dibenak masyarakat Indonesia bahwa Jakarta dikenal sebagai daerah yang maju dan modern.

Sebagai iku kota negara, banyak ciri khas Jakarta yang telah dikenal oleh masyarakat Indonesia, salah satunya adalah keberadaan Monumen Nasional atau yang lebih dikenal dengan sebutan Monas. Monumen nasional merupakan ikon khas Jakarta sebagai ibu kota negara. Dimana tugu ini mengambarkan perjuangan bangsa Indonesia dalam melawan penjajahan

Monumen nasional memiliki koleksi yang berkaitan dengan sejarah indonesia, diantaranya berbagai macam diorama yang menceritakan nilai sejarah perjuangan bangsa Indonesia. Monumen nasional memiliki 4 bagian ruangan yaitu Museum, cawan, ruang kemerdekaan dan puncak Monas dengan ketinggian 132 meter dimana di puncak monumen nasional terdapat emas seberat $50 \mathrm{~kg}$

Seiring berkembangnya waktu, monumen nasional kini menjadi salah satu destinasi kunjungan wisatawan, baik domestik maupun mancanegara. Dimana kunjungan wisatawan ke monumen nasional mengalami fluktuatif. Data kunjungan wisatawan secara lebih jelas dapat dilihat pada gambar sebagai berikut:

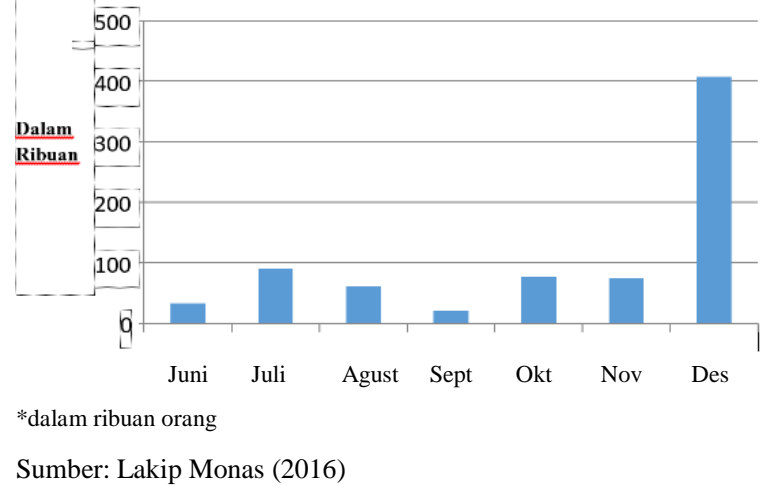

Gambar I

Grafik Data Kunjungan Monumen Nasional 2016

Berdasarkan Gambar I, Pengunjung Kawasan Monumen Nasional semakin meningkat setiap waktunya. Pengunjung di kawasan Monumen Nasional pada Juni 2016 hingga november mengalami naik turun dan puncaknya terjadi peningkatan pengunjung yaitu pada Desember 2016 sekitar 4000 pengunjung dikarenakan libur akhir tahun.

Monument nasional mengalami tingkat kunjungan wisatawan yang fluktuatif, hal tersebut dapat disebabkan oleh banyak faktor, salah satunya disebabkan oleh tidak maksimlanya pelayanan yang diberikan kepada pengunjung. Berdasarkan hasil wawancara yang telah dilakukan selama pra penelitian, 8 dari sepuluh wisatawan merasa tidak puas terhadap pelayanan yang diberikan selama mengunjungi monumen nasional. Ketidakpuasan tersebut disebabkan oleh berbagai faktor, diantaranya pada tidak maksimalnya fasilitas yang diberikan kepada wisatawan seperti jumlah air conditioner (AC) yang tidak memadai di dalam ruang museum yang menyebabkan ketidaknyamanan bagi wisatawan, selain itu juga tidak adanya papan petunjuk arah bagi wisatawan dan kurang terawatnya media informasi yang berada didalam museum dan fasilitas lainya yang berdampak pada ketidakpuasan wisatawan ketika berkunjung.

Kepuasan merupakan faktor penting yang harus diperhatikan oleh setiap perusahaan. kepuasan mampu menjadi nilai lebih yang dimiliki oleh perusahaan dalam meningkatkan pendapatanya. Kepuasan adalah perasaan senang atau kecewa seseorang yang muncul setelah membandingkan antara kinerja atau hasil yang dipikirkan terhadap kinerja atau hasil yang diharapkan, jika kinerja gagal memenuhi ekspektasi maka pelanggan tidak akan puas. (Akbar, 2014).

Banyak faktor yang mampu mempengaruhi kepuasan wisatawan ketika mengunjungi suatu 
destinasi wisata, salah satunya pada pelayanan yang diberikan. Pelayanan adalah kegiatan yang dapat diidentifikasi dan bersifat media penghubung antara satu pihak dengan pihak lain dengan maksud dan tujuan tertentu (Priyanto \& Hermawan, 2017). Lebih jauh kualitas pelayanan terhadap kepuasan pelanggan dapat memberikan kontribusi kepada perusahaan dalam meningkatkan pendapatan jangka panjangnya melalui kemampuan perusahaan dalam melayani konsumenya secara maksimal (Akbar, 2014).

Kualitas pelayanan yang rendah dapat menimbulkan ketidakpuasan kepada konsumen, tidak hanya pada konsumen perusahaan tersebut saja, tetapi juga kepada orang lain. Karena konsumen yang mengalami ketidakpuasan akan menyampaikan kekecewaanya kepada sedikitnya 15 orang lainya (Aryani \& Rosinta, 2010).

Menurut para akademisi, kepuasan pelanggan merupakan konstruk yang berdiri sendiri dan dipengaruhi oleh kualitas layanan (Aryani \& Rosinta, 2010).

Konsep kualitas pelayanan dan kepuasan memiliki keterkaitan yang sangat erat. Sehingga secara teoritis mampu memberikan acuan yang komprehensif dalam membangun konstruk penelitian ini.

\section{KAJIAN PUSTAKA}

\section{Kualitas Pelayanan}

Menurut Tjiptono (2012) kualitas pelayanan adalah berfokus pada upaya pemenuhan kebutuhan dan keinginan konsumen serta ketepatan penyampaianya untuk mengimbangi harapan konsumen".

Lovelock memberikan penekanan bahwa hanya organisasi yang dapat memberikan kualitas baik saja yang akan dapat menempatkan perusahaan tersebut dalam suatu kompetisi yang dapat menguntungkan bagi perusahaan (Syarifuddin, 2014). Untuk mengetahui seberapa baik kualitas pelayanan yang diberikan kepada wisatawan oleh suatu perusahaan atau organisasi, maka diperlukan kriteria penilaian yang komprehensif dalam mengakomodir berbagai aspek yang terdapat dalam suatu destinasi wisata, salah satunya melalui pengukuran dimensi kualitas pelayananya. Terdapat lima dimensi yang dapat dijadikan alat ukur dalam menilai kualitas pelayanan suatu perusahaan, diantaranya adalah sebagai berikut:

1. Dimensi Tampilan fisik (Tangible) berkenaan dengan daya tarik fisik, perlengkapan dan material yang digunakan perusahaan, serta penampilan karyawan.
2. Dimensi Realibilitas (Reliability) berkaitan dengan kemampuan perusahaan untuk memberikan layanan yang akurat sejak pertama kali tanpa membuat kesalahan apapun dan menyampaikan jasanya sesuai dengan waktu yang disepakati.

3. Dimensi Daya Tanggap (Responsiveness) berkenaan dengan kesediaan dan kemampuan para karyawam untuk membantu para pelanggan dan merespon permintaan mereka, serta kapan jasa akan diberikan dan kemudian memberikan jasa secara cepat.

4. Dimensi Jaminan (Assurance) yakni para karyawan mampu menumbuhkan kepercayaan pelanggan terhadap perusahaan bisa menciptakan rasa aman bagi para pelanggannya. Jaminan juga berarti bahwa para karyawan selalu bersikap sopan dan menguasai pengetahuan dan keterampilan yang dibutuhkan untuk menangani setiap pertanyaan atau masalah pelanggan.

5. Dimensi Empati (Emphaty) berarti bahwa perusahaan memahami masalah para pelanggannya dan bertindak demi kepentingan pelanggan, serta memberikan perhatian personal kepada para pelanggan dan memiliki jam operasi yang nyaman (Tjiptono, 2012).

\section{Kepuasan Pengunjung}

Kepuasan adalah perasaan senang atau kecewa seseorang yang muncul setelah membandingkan antara kinerja produk yang dipikirkan terhadap kinerja atau hasil yang diharapkannya, jika kinerja suatu produk memenuhi atau melebihi ekspektasi dari pelanggan maka akan tercipta rasa puas dan sangat puas pada diri pelanggan, sebaliknya jika kinerja produk berada dibawah harapan, maka seorang pelanggan akan merasa tidak puas (Kotler, 2011)

Menurut Westbrook \& Reily kepuasan adalah respon emosional terhadap pengalaman pengalaman berkaitan dengan produk atau jasa tertentu yang dibeli, gerai ritel, atau bahkan pola perilaku (seperti perilaku berbelanja dan perilaku pembeli), serta pasar secara keseluruhan (Tjiptono, 2014). Respon emosional dipicu oleh proses evaluasi kognitif yang membandingkan persepsi (atau keyakinan) terhadap obyek, tindakan atau kondisi tertentu dengan nilai-nilai (atau kebutuhan, keinginan dan hasrat) individual (Tjiptono, 2014) 
Adapun dimensi yang dapat digunakan dalam mengukur kepuasan menurut Dutka adalah sebagai berikut:

1. Attributes Related To Product yaitu dimensi kepuasan yang berkaitan dengan atribut dari produk seperti penetapan nilai yang didapatkan dengan harga, kemampuan produk menentukan kepuasan, benefit dari produk tersebut.

2. Attributes Related To Service yaitu dimensi kepuasan yang berkaitan dengan atribut dari pelayanan misalnya dengan garansi yang dijanjikan, proses pemenuhan pelayanan atau pengiriman, dan proses penyelesaian masalah yang diberikan.

3. Attributes Related To Purchase yaitu dimensi kepuasan yang berkaitan dengan atribut dari keputusan untuk membeli atau tidaknya dari produsen seperti kemudahan mendapat informasi, kesopanan karyawan dan juga pengaruh reputasi perusahaan (Saidani, 2012)

\section{METODE PENELITIAN}

Metode penelitian merupakan cara ilmiah untuk mendapatkan data yang valid dengan tujuan dapat ditemukan, dikembangkan, dan buktikan pada suatu pengetahuan tertentu sehingga pada gilirannya dapat digunakan untuk memahami, memecahkan, dan mengantisipasi masalah. (Sugiyono, 2016). Adapun metode yang digunakan dalam penelitian ini adalah metode kuantitatif dengan pendekatan deskriptif verifikatif, yaitu untuk mengukur sejauhmana pengaruh kualitas pelayanan yang diberikan oleh pengelola monumen nasional terhadap kepuasan wisatawan yang berkunjung.

Populasi dalam penelitian ini adalah wisatawan yang melakukan kunjungan ke monumen nasional. populasi mengacu pada data tingkat kunjungan terbaru yang diperoleh, yaitu pada bulan Juni 2018 sebanyak 191.398 pengunjung dan persen kelonggaran yang ditentukan adalah sebesar 50 persen. Berdasarkan data kunjungan tersebut maka sampel dalam penelitian ini adalah sebagai berikut:

$$
\begin{aligned}
& \mathrm{n}=\frac{191.398}{1+191.398(0,1)^{2}} \\
& \mathrm{n}=99,947
\end{aligned}
$$

Untuk memudahkan perhitungan maka jumlah sampel yang diambil dibulatkan menjadi 100 orang.

Dalam upaya untuk memperolah data penelitian, maka data yang diperoleh dilakukan melalui metode pengambilan data sebagai berikut:
1. Observasi

Adalah suatu usaha sadar untuk mengumpulkan data yang dilakukan secara sistematis dengan prosedur terstandar atau (Suharsimi, 2013). Observasi dilakukan untuk memperoleh data yang terkait dengan kualitas pelayanan dan kepuasan pengunjung di monumen nasional melalui kegiatan pengamatan dan pendokumentasian kondisi dilapangan secara langsung.

2. Wawancara

Metode wawancara merupakan teknik pengumpulan data apabila peneliti ingin melakukan studi pendahuluan untuk menemukan permasalahan yang harus diteliti, dan juga mengetahui hal-hal dari responden yang lebih mendalam dan jumlah respondennya sedikit/kecil. (Sugiyono, 2014). Wawancara dilakukan untuk mendapatkan informasi yang akurat dari narasumber mengenai berbagai kondisi dan permasalahan yang terjadi di monumen nasional.

3. Kuesioner

Kuesioner merupakan teknik pengumpulan data yang efesien apabila peneliti tahu dengan siapa variabel akan diukur dan tahu apa yang bisa diharapkan dari responden. Kuesioner dapat berupa pertanyaanpertanyaan tertutup atau terbuka, dapat diberikan kepada responden secara langsung atau dikirim melaui pos atau internet. (Sugiono, 2014). Sedangkan Arikunto mendefinisikan Kuesioner adalah sejumlah pertanyaan tertulis yang digunakan untuk memperoleh informasi dari responden dalam arti laporan tentang pribadinya atau hal-hal yang ia ketahui (Suharsimi, 2013). Pembagian kuesioner dilakukan untuk mengetahui respon wisatawan terhadap kualitas pelayanan di monumen nasional

4. Studi Pustaka

Studi pustaka dilakukan untuk memperoleh berbagai data melalui pohak ketiga seperti : jurnal, majalah, website dan media lainya yang memiliki keterkaitan dengan monumen nasional.

\section{HASIL DAN PEMBAHASAN}

\section{Analisis Deskriptif Variabel Penelitian}

Berdasarkan hasil analisa yang peneliti lakukan diketahui bahwa hasil skor interval, maka skor total variabel Kualitas Pelayanan sebesar 3.071 berada pada interval 1.000-5.000 dan termasuk 
ke dalam kategori "Baik". Artinya, Kualitas Pelayanan di Monumen Nasional Jakarta ditanggapi "Baik" oleh responden.

Berdasarkan hasil analisa yang peneliti lakukan diketahui bahwa hasil skor interval, maka skor total variabel Kepuasan Pengunjung sebesar 3.251 berada pada interval 1.000-5.000 dan termasuk ke dalam kategori "Baik". Artinya, Kepuasan Pengunjung di Monumen Nasional Jakarta ditanggapi "Baik" oleh responden.

\section{Uji Asumsi Klasik}

\section{Uji Normalitas}

Berdasarkan hasil uji SPSS Menunjukan bahwa nilai Asymp Sig. dari masing-masing variable > (lebih dari) signifikansi $\alpha(0,05)$. Variabel $\mathrm{X}$ (Kualitas Pelayanan) menunjukkan hasil yaitu 0.094 dan Variabel Y (Kepuasan Pengunjung) menunjukkan hasil yaitu 0.061. Dengan demikian, dapat disimpulkan bahwa data berdistribusi normal.

\section{Uji Heteroskedastisitas}

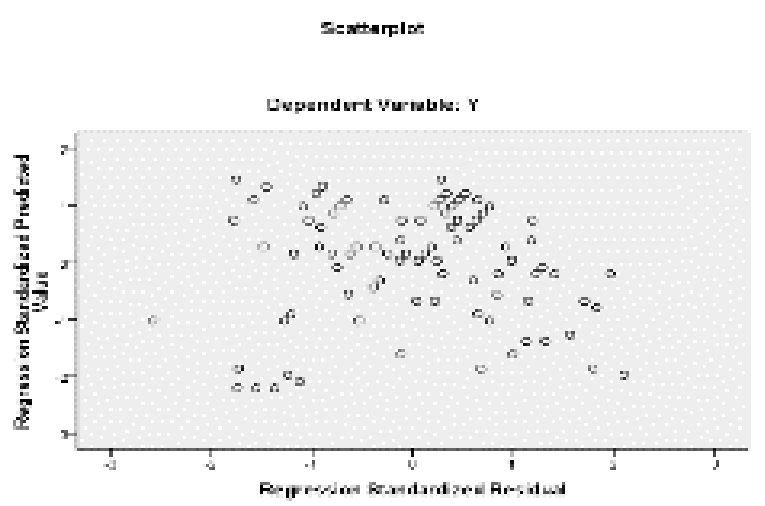

Gambar 2.

Hasil Uji Scatterplot

Berdasarkan Gambar IV.1. menunjukan hasil uji heteroskedastisitas. Dari gambar tersebut dapat dilihat bahwa model bersifat heteroskedastitas, yaitu adanya titik yang membentuk pola-pola tertentu secara teratur, baik di atas maupun di bawah angka 0 pada sumbu Y. Dengan demikian, dapat disimpulkan bahwa telah terjadi heteroskedastisitas pada model ini. Artinya, peningkatan nilai variabel dependen pada sumbu $\mathrm{X}$ tidak diikuti oleh peningkatan nilai residual.

\section{Uji Autokorelasi}

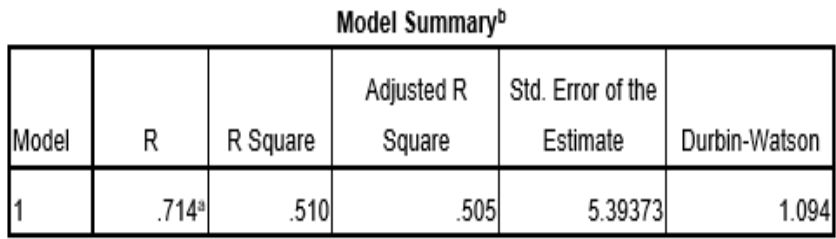

Adapun autokorelasi menurut (Santoso, 2012) ditentukan oleh kriteria sebagai berikut :

1) Jika $\mathrm{Dw}<-2$ maka terdapat autokorelasi positif.

2) Jika $-2 \leq 2$ maka tidak terdapat autokorelasi

3) Jika Dw > 2 maka terdapat autokorelasi negatif.

Dengan demikian dapat disimpulkan bahwa nilai DW $=1,094$ sehingga tidak terdapat autokorelasi dalam model ini.

\section{Analisis Regresi Linier Sederhana}

\begin{tabular}{|c|c|c|c|c|c|c|c|c|}
\hline \multicolumn{9}{|c|}{ Coefficients $^{a}$} \\
\hline \multirow[b]{2}{*}{ Mode } & & \multicolumn{2}{|c|}{$\begin{array}{l}\text { Unstandardized } \\
\text { Coefficients }\end{array}$} & \multirow{2}{*}{$\begin{array}{c}\begin{array}{c}\text { Standardized } \\
\text { Coefficients }\end{array} \\
\text { Beta }\end{array}$} & \multirow[b]{2}{*}{$t$} & \multirow[b]{2}{*}{ Sig. } & \multicolumn{2}{|c|}{$\begin{array}{l}\text { Collinearity } \\
\text { Statistics }\end{array}$} \\
\hline & & B & Std. Error & & & & Tolerance & VIF \\
\hline 1 & (Constant) & 12.612 & 2.042 & & 6.177 & .000 & & \\
\hline & $x$ & .648 & .064 & .714 & 10.104 & .000 & 1.000 & 1.000 \\
\hline
\end{tabular}

Berdasarkan hasil uji SPSS Menunjukan hasil uji regresi linear sederhana. Model persamaan regresi yang dapat dituliskan dari hasil uji regresi sederhana diatas dalam persamaan regresi bentuk standar adalah sebagai berikut:

Persamaan regresi hasil uji tersebut dapat di jelaskan sebagai berikut, koefesien regresi variabel Kualitas pelayanan berpengaruh positif terhadap kepuasan pengunjung. Koefesien regresi untuk X sebesar 0,714 dan bertanda positif dengan signifikansi 0,000 . Hal ini berarti bahwa setiap peningkatan perubahan nilai kualitas pelayanan akan memberikan peningkatan skor sebesar 0,714. Berdasarkan persamaan dan keterangan diatas dapat diketahui bahwa variabel bebas kualitas pelayanan berpengaruh terhadap variabel terikat kepuasan pengunjung sebesar 0,714 . 


\section{Uji Koefisien Determinasi}

\begin{tabular}{|l|r|r|r|r|r|}
\hline \multicolumn{7}{|c|}{ Model Summary $^{\mathrm{D}}$} \\
\hline Model & \multicolumn{1}{|c|}{$\mathrm{R}$} & R Square & $\begin{array}{c}\text { Adjusted R } \\
\text { Square }\end{array}$ & $\begin{array}{c}\text { Std. Error of the } \\
\text { Estimate }\end{array}$ & Durbin-Watson \\
\hline 1 & $.714^{\mathrm{a}}$ & .510 & .505 & 5.39373 & 1.094 \\
\hline
\end{tabular}

Analisis koefisien determinasi dilakukan untuk menentukan besarnya kualitas pelayanan berpengaruh terhadap kepuasan pengunjung. Hasil uji koefisien determinasi $\left(\mathrm{r}^{2}\right)$ dari tabel di atas, dapat dilihat bahwa nilai $\mathrm{R}$ square $=0,505$. Adapun proses perhitungannya adalah sebagai berikut :

Rumus untuk mencari Korelasi Determinasi (KD) adalah :

$$
\mathrm{KD}=\mathrm{r}^{2} \times 100 \%
$$

Keterangan :

$\mathrm{KD}=$ Merupakan seberapa jauh perubahan variabel $\mathrm{Y}$ dipengaruhi oleh perubahan variabel $\mathrm{X}$

$\mathrm{r}^{2} \quad=$ Kuadrat koefisien korelasi

$\mathrm{KD}=\mathrm{r}^{2} \mathrm{X} 100 \%$

$=0,714^{2} \times 100 \%$

$=0,510 \times 100 \%$

$=51 \%$

Mengacu pada hasil perhitungan di atas, maka dapat diindikasikan bahwa kualitas pelayanan kolerasi berpengaruh dengan kepuasan pengunjung sebesar $51 \%$, sedangkan sisanya, yaitu $49 \%$ dipengaruhi oleh variabel-variabel lain yang tidak diteliti dalam penelitian ini.

\section{Uji T}

\begin{tabular}{|c|c|c|c|c|c|c|c|c|}
\hline \multicolumn{9}{|c|}{ Coefficients $^{\mathrm{a}}$} \\
\hline \multirow[b]{2}{*}{ Model } & & \multicolumn{2}{|c|}{$\begin{array}{c}\text { Unstandardized } \\
\text { Coefficients }\end{array}$} & \multirow{2}{*}{$\begin{array}{c}\text { Standardized } \\
\text { Coefficients } \\
\text { Beta } \\
\end{array}$} & \multirow[b]{2}{*}{$t$} & \multirow[b]{2}{*}{ Sig. } & \multicolumn{2}{|c|}{ Collinearity Statistics } \\
\hline & & B & Std. Error & & & & Tolerance & $\mathrm{VIF}$ \\
\hline 1 & (Constant) & 12.612 & 2.042 & & 6.177 & .000 & & \\
\hline & $x$ & .648 & .064 & .714 & 10.104 & .000 & 1.000 & 1.000 \\
\hline
\end{tabular}

Melihat hasil uji $\mathrm{T}$ tersebut adalah pengaruh kualitas terhadap kepuasan pengunjung secara parsial menghasilkan nilai $\mathrm{t}$ hitung $=10,104$ dan signifikansi hitung $=0,000$. Dengan menggunakan signifikansi $\alpha(0,05)$ dan derajat kebebasan (df) n-k atau 100-18 = $82(n=$ jumlah responden dan $\mathrm{k}=$ jumlah variabel independent dan dependent), diperoleh $t$ tabel sebesar 1,66. Artinya, $t$ hitung lebih besar dari $t$ tabel dan signifikansi hitung lebih kecil dari signifikansi $\alpha$. Dengan demikian, $\mathrm{H}_{0}$ ditolak dan $\mathrm{H}_{\mathrm{a}}$ diterima dengan keterangan sebagai berikut:

a. $\mathrm{H}_{0}$ : $\rho y x=0$ Kualitas Pelayanan tidak berpengaruh terhadap Kepuasan Pengunjung secara parsial.

b. $\mathrm{H}_{\mathrm{a}}$ : pyx $\neq 0$ Kualitas Pelayanan berpengaruh terhadap Kepuasan Pengunjung secara parsial.

\section{Pembahasan}

Pelayanan prima merupakan hal yang sangat penting dilakukan oleh Monumen Nasional jika ingin memperoleh kualitas pelayanan yang baik akan berdampak pada kepuasan pengunjung sehingga dapat meningkatkan loyalitas pengunjung terhadap pelayanan yang diberikan. Menurut Wyock yang dikutip oleh (Tjiptono, 2014) kualitas pelayanan merupakan "tingkat keunggulan (Excellent) yang diharapkan dan pengendalian atas keunggulan tersebut untuk memenuhi kebutuhan konsumen".

Monumen Nasional harus benar-benar memperhatikan kepuasan pengunjung sehingga pengunjung merasa senang ataupun puas dengan pelayanan yang diberikan. Sehingga pengunjung datang kembali di masa yang akan datang ke Monumen Nasional. Hal ini sejalan dikemukakan oleh Kotler dalam (Lupiyoadi, 2013) bahwa "Kepuasan merupakan tingkat perasaan dimana seseorang menyatakan hasil perbandingan atas kinerja produk jasa yang diterima dengan yang diharapkan".

Berdasarkan hasil penelitian ini bahwa kualitas pelayanan secara parsial tangibles (bukti fisik), realibility (keandalan), rensponsiveness (ketanggapan), assurance (Jaminan) dan emphaty (empati) dan kepuasan pengunjung menujukan hasil interval skor yang baik sehingga pelayanan di Monumen Nasional dinyatakan baik. Kualitas pelayanan memiliki hubungan atau korelasi antara kepuasan pengunjung sebesar 51\%, sedangkan sisanya, yaitu $49 \%$ dipengaruhi oleh variabel-variabel lain yang tidak diteliti dalam penelitian ini. Hasil Uji Hipotesis pengaruh kualitas pelayanan terhadap kepuasan pengunjung secara parsial dengan standar error 0,05 dapat dilihat bahwa $\mathrm{T}$ hitung $>\mathrm{T}$ tabel yaitu 10,104 > 1,66 ,bahwasanya Ha diterima sehingga kualitas pelayanan berpengaruh secara signifikan terhadap kepuasan pengunjung. Hal ini sesuai dengan penelitian dengan kajian terdahulu Dwi Prasetyo dengan judul Pengaruh Kualitas 
Pelayanan Terhadap Kepuasan Pengunjung pada Obyek Wisata Taman Rekreasi Pantai Kartini Rembang bahwa kualitas pelayanan memberikan kontribusi secara parsial tangibles (bukti fisik), relibility (keandalan), rensponsiveness (ketanggapan), assurance (Jaminan) dan emphaty (empati) signifikan terhadap kepuasan pengunjung. Selain itu hasil penelitian ini juga sesuai dengan hasil penelitian yang telah dilakukan oleh Siti Fatimah dengan judul Pengaruh Kualitas pelayanan terhadap kepuasan berkunjung di taman objek wisata di situ patenggang, dimana hasil penelitian menunjukkan bahwa kualitas pelayanan mempengaruhi kepuasan pengunjung berpengaruh positif di Taman Objek Wisata Situ Patenggang.

\section{SIMPULAN DAN REKOMENDASI}

Penelitian dengan judul "Pengaruh Kualitas Pelayanan Terhadap Kepuasan Pengunjung Di Monumen Nasional Jakarta" ini bertujuan untuk mengetahui gambaran Kualitas Pelayanan pada Monumen Nasional Jakarta, untuk mengetahui pengaruh kepuasan pengunjung di Monumen Nasional serta untuk mengetahui pengaruh kualitas pelayanan terhadap kepuasan pengunjung di Monumen Nasional Jakarta. Sumber Data mengenai perusahaan diperoleh melalui internet, observasi lapangan, dan wawancara terhadap staff dan karyawan Monumen Nasional Jakarta. Sedangkan, sumber data mengenai karakteristik responden diperoleh melalui pengisian identitas dan tanggapan responden pengunjung Monumen Nasional yang dijadikan responden oleh peneliti.

Berdasarkan dari interval skor penelitian, maka skor total variabel Kualitas Pelayanan termasuk ke dalam kategori "Baik". Artinya, Kualitas Pelayanan di Monumen Nasional Jakarta ditanggapi "Baik" oleh responden. Dalam penelitian ini, pernyataan "Keamanan Pengunjung terjamin dengan adanya petugas keamanan pamdal (security)" dan "Petugas pelayanan menyapa dengan ramah kepada pengunjung" mendapatkan skor terendah hal ini membuktikan bahwa kurangnya kemanan dan keramahan petugas pelayanan yang mengakibatkan kepuasan pengunjung menjadi berkurang.

Berdasarkan dari interval skor penelitian, maka skor total variabel Kepuasan Pengunjung termasuk ke dalam kategori "Baik". Artinya, Kepuasan Pengunjung di Monumen Nasional Jakarta ditanggapi "Baik" oleh responden namun, pernyataan "Pengunjung merasa puas dengan fasilitas yang berada di Monumen Nasional" mendapatkan respon terendah hal ini menunjukkan bahwa pengunjung merasa tidak puas dengan fasilitas yang ada sehingga menimbulkan banyak keluhan yang ada.

Mengacu pada hasil perhitungan analisis dalam penelitian ini, maka kualitas pelayanan berpengaruh secara positif dan signifikan terhadap kepuasan pengunjung di Monumen Nasional Jakarta.

Meningkatkan Keamanan dan kenyamanan bagi Pengunjung dengan dilakukanya briefing pada sebelum dan setelah kegiatan operasional. Sehingga setiap unsur yang berada di lingkup pengelola minumen nasional mampu memahami dengan baik tugas dan tanggung jawabnya dalam memberikan pelayanan kepada pengunjung. Meningkatkan fasilitas yang ada dengan memperbaiki lampu penerangan diorama, media informasi seperti papan penunjuk arah yang perlu ditambah di Monumen Nasional dan dan penambahan kereta wisata agar pengunjung merasa puas dengan pelayanan yang diberikan di Monumen Nasional. Mengevaluasi kembali setiap aktifitas dan kegiatan dalam melayani pengunjung, kriteria evaluasi kinerja dapat dilakukan dengan memperhatikan faktor apa saja yang mampu mempengaruhi kepuasan wisatawan saat berkunjung.

\section{DAFTAR PUSTAKA}

Akbar, M. (2014). Pengaruh Kualitas Pelayanan Terhadap Kepuasan Pelanggan, 1-19, 1-19.

Aryani. D, Rosinta. F. 2010. Pengaruh Kualitas Layanan terhadap Kepuasan Pelanggan dalam Membentuk Loyalitas Pelanggan. Jurnal Bisnis \& Birokrasi, Jurnal Ilmu Administrasi dan Organisasi. Volume 17, No. 2

Dwi Prasetyo. 2009. Pengaruh Kualitas Pelayanan Terhadap Kepuasan Pengunjung Pada Obyek Wisata Taman Rekreasi Pantai Kartini Rembang. Universitas Negeri Semarang

Fatimah.S, Oda I.B. Hariyanto. 2016. Pengaruh Kualitas Pelayanan Terhadap Kepuasan Berkunjung Di Taman Objek Wisata Situ Patenggang. Jurnal Pariwisata. Vol 3, No 1

Kotler,P.(2011).KotlerManagementDecision.http s://doi.org/10.1108/00251749110004961

Lupiyoadi. (2013). Manajemen Pemasaran Jasa. In Edisi Kedua, Penerbit Salemba Empat, Jakarta. 
Priyanto, R., \& Hermawan, H. (2017). Pengaruh Kualitas Pelayanan terhadap Kepuasan Wisatawan serta Dampaknya terhadap Loyalitas ( Studi di Ciater Spa Resort ).

Saidani, B., \& Arifin, S. (2012). Pengaruh Kualitas Produk Dan Kualitas Layanan Terhadap Kepuasan Konsumen Dan Minat Beli Pada Ranch Market. Jurnal Riset Manajemen Sains Indonesia.

Sugiyono. 2014. Metode Penelitian Kunatitatif Kualitatif dan R\&D. Bandung Alfabeta.

Sugiyono. (2016). Metode Penelitian Kualitatif. Bandung: Alfabeta.

Suharsimi, A. (2013). Metodologi Penelitian. Bumi aksara.

Syarifuddin, Didin. 2012. Building Service Quality, Increasing Guest Satisfaction. Bandung: Manajemen Pariwisata, STP ARS Internasional.

https://www.researchgate.net/profile/Didin_S yarifuddin/publication/284027952

Syarifuddin, D. (2014). Measuring Destination Service Quality ( Studi Tentang Pelaksanaan Kualitas Pelayanan Kebun Binatang Bandung ), $I(2)$.

Tjiptono, F. (2012). Service Management Mewujudkan Layanan Prima. In Edisi 2. https://doi.org/2012

Tjiptono, F. (2014). Pemasaran Jasa - Prinsip, Penerapan, dan Penelitian. Yogyakarta: Andi Offset. 